www.jmscr.igmpublication.org

Index Copernicus Value: 79.54

ISSN (e)-2347-176x ISSN (p) 2455-0450

crossref DOI: https://dx.doi.org/10.18535/jmscr/v7i4.142

Journal Of Medical Science And Clinical Research

IGM Publication

An official Publication of IGM Publication

\title{
A Study of Attitude Assessment Regarding HIV/AIDS in the Urban and Rural Field Practice Area of Department of Community Medicine, MMIMSR, Mullana, Ambala (Haryana)
}

\author{
Authors \\ Choudhary K, Mittal A, Bhardwaj A, Chaudhry C
}

\begin{abstract}
Background: Discovered in 1980s, AIDS, which breaks down human body's immune response, is still infecting lacs and lacs of people every year. Assessing the attitude of people towards HIV/AIDS could possibly give us some solutions for the problem, given the availability of no cure nor any vaccine as of yet. Therefore, the present study to assess the attitude of population in Ambala was undertaken so that vulnerable groups could be identified and transmission of the infection could be prevented.

Methodology: A community based cross-sectional study was carried out among the population residing in the urban and rural field practice area of department of Community Medicine, MMIMSR Mullana, Ambala from January 2015 to December 2015. Systemic randomization was done and a total of 1000 participants were interviewed and the data collected was analysed by SPSS version 20.

Results: $94 \%$ of the study subjects said that people should sympathize with HIV infected individuals. $12.4 \%$ of the participants thought that sharing food, combs, sheets or sitting closely with an infected person and 10.8\% thought that shaking hands, touching or holding hands in a normal way could also spread the infection.

Conclusion: Though the study subjects had favourable attitudes towards HIV/AIDS, still there were many lacunae in certain areas, which demand for extensive IEC activities to reinforce positive attitude.

Keywords: HIV, AIDS, Attitude, Assessment.
\end{abstract}

\section{Introduction}

In the nearly three decades since its discovery, AIDS has generated extraordinary interest and sustained publicity, often characterized by fear and hysteria. There are many reasons for this reaction, including the public's fear and prejudice towards the groups comprising nearly all of the first AIDS patients and the misconception that AIDS was highly contagious. More and better health communication strategies and products are needed. Their application holds the best hope for the future of HIV prevention. There remains much for all of us to do.
The situation becomes very difficult for HIV infected people who face rejection and dejection from their community. Traditional communities and their social milieu further worsen the scenario. These factors impede timely helpseeking ${ }^{11}$.

Therefore, the present study was undertaken with the AIM to assess theattitude towards HIV/AIDS among the population residing in the urban and rural field practice area of the department of community medicine and to study the influence of socio-demographic predictors. 


\section{Material and Methods}

A community based cross-sectional dtudy was undertaken over a period of one year (January to December 2015) in the urban and rural field practice area of the Department of Community Medicine, Maharishi Markandeshwar Institute of Medical Sciences and Research, Mullana, Ambala (Haryana).

A rounded off sample size of 1000 was arrived at, by taking the prevalence of $30 \%{ }^{13}$. Out of this 500 were from urban and 500 from rural area.

People less than 15 years of age or/and unwilling to participate were excluded from the study. The participants were assessed for their attitude regarding HIV/AIDS using a self-designed, pretested and semi-structured questionnaire.

The data collected during the study was converted into electronic format by entering into Microsoft Excel. Data was analysed by IBM SPSS (Statistical Package for Social Sciences) version 20 statistical software. Percentages were calculated and Chi-square test was used to determine statistical significance between the study subject's knowledge, attitude, practices and their socio-demographic profiles. A p-value of less than 0.05 was considered significant at $95 \%$ confidence interval. Permission was obtained from Institutional Ethics Committee before conduct of the study. No financial implications in form of any drug usage or conduction of any laboratory tests etc. was involved.

Due consent was sought from all the participants, before getting the proforma filled. The consent form was both in Hindi as well as English. Those not willing were respectfully excluded from the study.

\section{Observations and Results}

In our study almost half (47\%) of the participants, i.e., 470 , in the study were in the age group of 18 30 years. A total of $584(58.4 \%)$ males and 416 $(41.6 \%)$ females participated in the study.784 (78.4\%) Hindus, 94 (9.4\%) Sikhs, 84 (8.4\%) Muslims and 38 (3.8\%) Christians, participated in the study.

$108(10.8 \%)$ of all the respondents were illiterate. Almost one-fourths $(24.6 \%)$ of the participants were graduates and a mere $6.4 \%$ (64) were postgraduates. 236 participants had studied up to senior secondary, 92 up to matric, 68 up to middle and 64 up to primary. There were 122 diploma holders

Table No.1: Distribution of Study Subjects as per their Socio-Economic Status

\begin{tabular}{|c|c|c|c|}
\hline $\begin{array}{c}\text { Socio-Economic } \\
\text { Class }\end{array}$ & $\begin{array}{c}\text { Urban } \\
(\mathbf{N}=\mathbf{5 0 0})\end{array}$ & $\begin{array}{c}\text { Rural } \\
(\mathbf{N}=\mathbf{5 0 0})\end{array}$ & $\begin{array}{c}\text { Total } \\
(\mathbf{N = ~ 1 0 0 0 )}\end{array}$ \\
\hline I & $476(95.2 \%)$ & $404(80.8 \%)$ & $880(88 \%)$ \\
\hline II & $20(4 \%)$ & $76(15.2 \%)$ & $96(9.6 \%)$ \\
\hline III & $2(0.4 \%)$ & $18(3.6 \%)$ & $20(2 \%)$ \\
\hline IV & $2(0.4 \%)$ & 0 & $2(0.2 \%)$ \\
\hline V & 0 & $2(0.4 \%)$ & $2(0.2 \%)$ \\
\hline
\end{tabular}

Table no.2 : Discriminatory attitude of people regarding HIV/AIDS

\begin{tabular}{|l|c|c|c|c|}
\hline \multirow{2}{*}{ Questions asked } & $\begin{array}{c}\text { Urban } \\
(\mathbf{N = 5 0 0})\end{array}$ & $\begin{array}{c}\text { Rural } \\
(\mathbf{N}=\mathbf{5 0 0})\end{array}$ & $\begin{array}{c}\text { Total } \\
(\mathbf{N}=\mathbf{1 0 0 0})\end{array}$ \\
\hline $\begin{array}{l}\text { Is AIDS a frightening and } \\
\text { fatal disease? }\end{array}$ & Agree & $470(94 \%)$ & $382(76.4 \%)$ & $852(85.2 \%)$ \\
\cline { 2 - 5 } & Disagree & $14(2.8 \%)$ & $72(14.4 \%)$ & $86(8.6 \%)$ \\
\cline { 2 - 5 } & Don't know & $16(3.2 \%)$ & $46(9.2 \%)$ & $62(6.2 \%)$ \\
\hline $\begin{array}{l}\text { Should HIV people be } \\
\text { discriminated with? }\end{array}$ & Agree & $12(2.4 \%)$ & $18(3.6 \%)$ & $30(3 \%)$ \\
\cline { 2 - 5 } & Disagree & $480(96 \%)$ & $468(93.6 \%)$ & $948(94.8 \%)$ \\
\cline { 2 - 5 } & Don't know & $8(1.6 \%)$ & $14(2.8 \%)$ & $22(2.2 \%)$ \\
\hline $\begin{array}{l}\text { Should HIV patients be } \\
\text { forced to live away from } \\
\text { others? }\end{array}$ & Agree & $18(3.6 \%)$ & $14(2.8 \%)$ & $32(3.2 \%)$ \\
\cline { 2 - 5 } & Disagree & $474(94.8)$ & $474(94.8 \%)$ & $948(94.8 \%)$ \\
\cline { 2 - 5 } & Don't know & $8(1.6 \%)$ & $12(2.4 \%)$ & $20(2 \%)$ \\
\hline
\end{tabular}


When asked if AIDS is a fatal and frightening disease, $852(85.2 \%)$ of our study subjects agreed. 948 (94.8\%) disagreed that HIV people should be discriminated with and the same number also disagreed that HIV patients be forced to live away from others.
$940(94 \%)$ of the respondents agreed that people should sympathize with HIV infected people. When asked if people should realize that they could get infected if they were not careful, 920 (92\%) agreed. Majority of the participants (90.4\%) agreed that they would get tested had they thought they might had HIV.

Figure no.1: Sympathetic and careful attititude of URBAN study subjects towards HIV

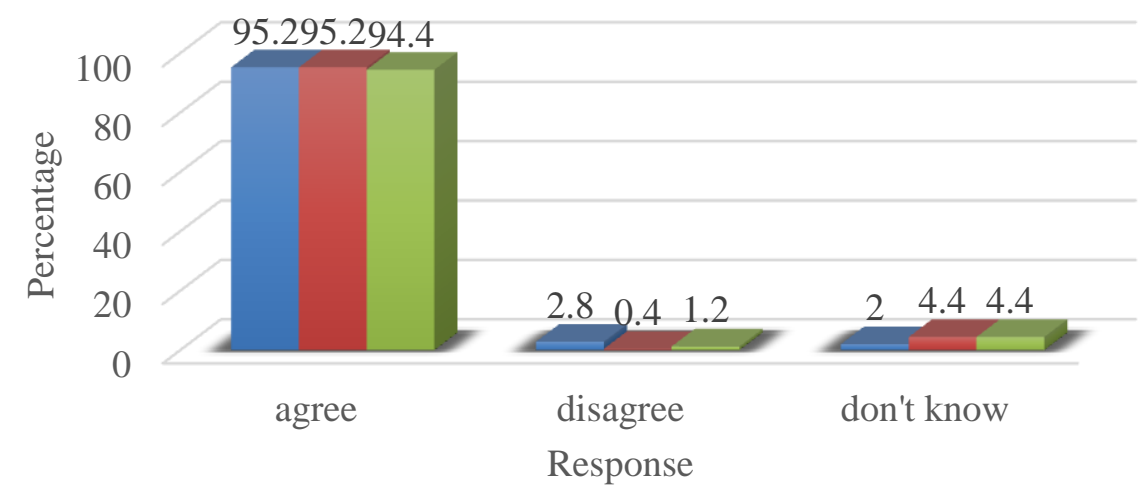

- People should sympathize with infected people

- People should realize that if they are not careful,they could get infected Would get tested,had I thought I might have HIV

Table No. 3: Sociodemographic Factors Affecting Attitude of Study Subjects Regarding HIV/AIDS

\begin{tabular}{|c|c|c|c|c|c|c|}
\hline \multirow{2}{*}{\multicolumn{2}{|c|}{ Socio-demographic variables }} & \multicolumn{5}{|c|}{ Would you get tested, had you thought you might have HIV } \\
\hline & & \multirow{2}{*}{$\frac{\text { Agree }}{452(50 \%)}$} & \multirow{2}{*}{$\begin{array}{c}\text { Disagree } \\
6(25 \%)\end{array}$} & \multirow{2}{*}{$\frac{\text { Don't know }}{12(16.7 \%)}$} & \multirow{2}{*}{$\begin{array}{c}\text { Total }(1000) \\
470(47 \%)\end{array}$} & p-value \\
\hline \multirow[t]{4}{*}{ Age groups } & 18-30 years & & & & & \multirow{4}{*}{$<.001$} \\
\hline & $30-45$ years & $276(30.5 \%)$ & $4(16.7 \%)$ & $18(25 \%)$ & $298(29.8 \%)$ & \\
\hline & 45-60 years & $154(17 \%)$ & $8(33.3 \%)$ & $28(38.9 \%)$ & $190(19 \%)$ & \\
\hline & 60 years \& above & $22(2.4 \%)$ & $6(25 \%)$ & $14(19.4 \%)$ & $42(4.2 \%)$ & \\
\hline \multirow[t]{2}{*}{ Sex } & Male & $540(59.7 \%)$ & $10(41.7 \%)$ & $34(47.2 \%)$ & $584(58.4 \%)$ & \multirow[t]{2}{*}{.028} \\
\hline & Female & $364(40.3 \%)$ & $14(58.3 \%)$ & $38(52.8 \%)$ & $416(41.6 \%)$ & \\
\hline \multirow[t]{8}{*}{ Education } & Illiterate & $66(7.3 \%)$ & $8(33.3 \%)$ & $34(47.2 \%)$ & $108(10.8 \%)$ & \multirow{8}{*}{$<.001$} \\
\hline & Primary & $50(5.5 \%)$ & $4(16.7 \%)$ & $10(13.9)$ & $64(6.4 \%)$ & \\
\hline & Middle & $48(5.3 \%)$ & $2(8.3 \%)$ & $18(25 \%)$ & $68(6.8 \%)$ & \\
\hline & Matric & $84(9.3 \%)$ & $4(16.7 \%)$ & $4(5.6 \%)$ & $92(9.2 \%$ & \\
\hline & Senior secondary & $230(25.4 \%)$ & $6(25 \%) z$ & 0 & $236(23.6)$ & \\
\hline & Diploma & $118(13.1 \%)$ & 0 & $4(5.6 \%)$ & $122(12.2 \%)$ & \\
\hline & Graduate & $244(27 \%)$ & 0 & $2(2.8 \%)$ & $246(24.6 \%)$ & \\
\hline & Post-graduate & $64(7.1 \%)$ & 0 & 0 & $64(6.4 \%)$ & \\
\hline \multirow{5}{*}{$\begin{array}{l}\text { Socio- } \\
\text { economic } \\
\text { class }\end{array}$} & I & $818(90.5 \%)$ & $16(66.7 \%)$ & $46(63.9)$ & $880(88 \%)$ & \multirow{5}{*}{$<.001$} \\
\hline & II & $70(7.7 \%)$ & $6(25 \%)$ & $20(27.8 \%)$ & $96(9.6 \%)$ & \\
\hline & III & $14(1.5 \%)$ & 0 & $6(8.3 \%)$ & $20(2 \%)$ & \\
\hline & IV & $2(0.2 \%)$ & 0 & 0 & $2(0.2 \%)$ & \\
\hline & $\mathrm{V}$ & 0 & $2(8.3 \%)$ & 0 & $2(0.2 \%)$ & \\
\hline \multirow[t]{4}{*}{ Religion } & Hindu & $704(78 \%)$ & $22(91.7 \%)$ & $54(75 \%)$ & $780(78 \%)$ & \multirow{4}{*}{.011} \\
\hline & Sikh & $90(10 \%)$ & 0 & $4(5.6 \%)$ & $94(9.4 \%)$ & \\
\hline & Muslim & $68(7.5 \%)$ & $2(8.3 \%)$ & $14(19.4 \%)$ & $84(8.4 \%)$ & \\
\hline & Christian & $38(4.2 \%)$ & 0 & 0 & $38(3.8 \%)$ & \\
\hline
\end{tabular}


Further it was seen that age group, sex, education, socio-economic status and religion were all significantly associated $(p<.05)$ with the attitude of study subjects whether they would get tested had they thought they had HIV.

$760(76 \%)$ of the respondents agreed that condom is highly effective against HIV prevention. Only $42(4.2 \%)$ of the participants thought that a condom could be safely re-used. 708 (70.8\%) of the total participants agreed that "No Condom No Sex" is a good rule for protection from HIV. When asked if "Prevention is the only cure" in HIV/AIDS, 650 (65\%) agreed. An identical response was got when asked about $\mathrm{ABC}$, being an effective prevention, as 690 (69\%) participants agreed.

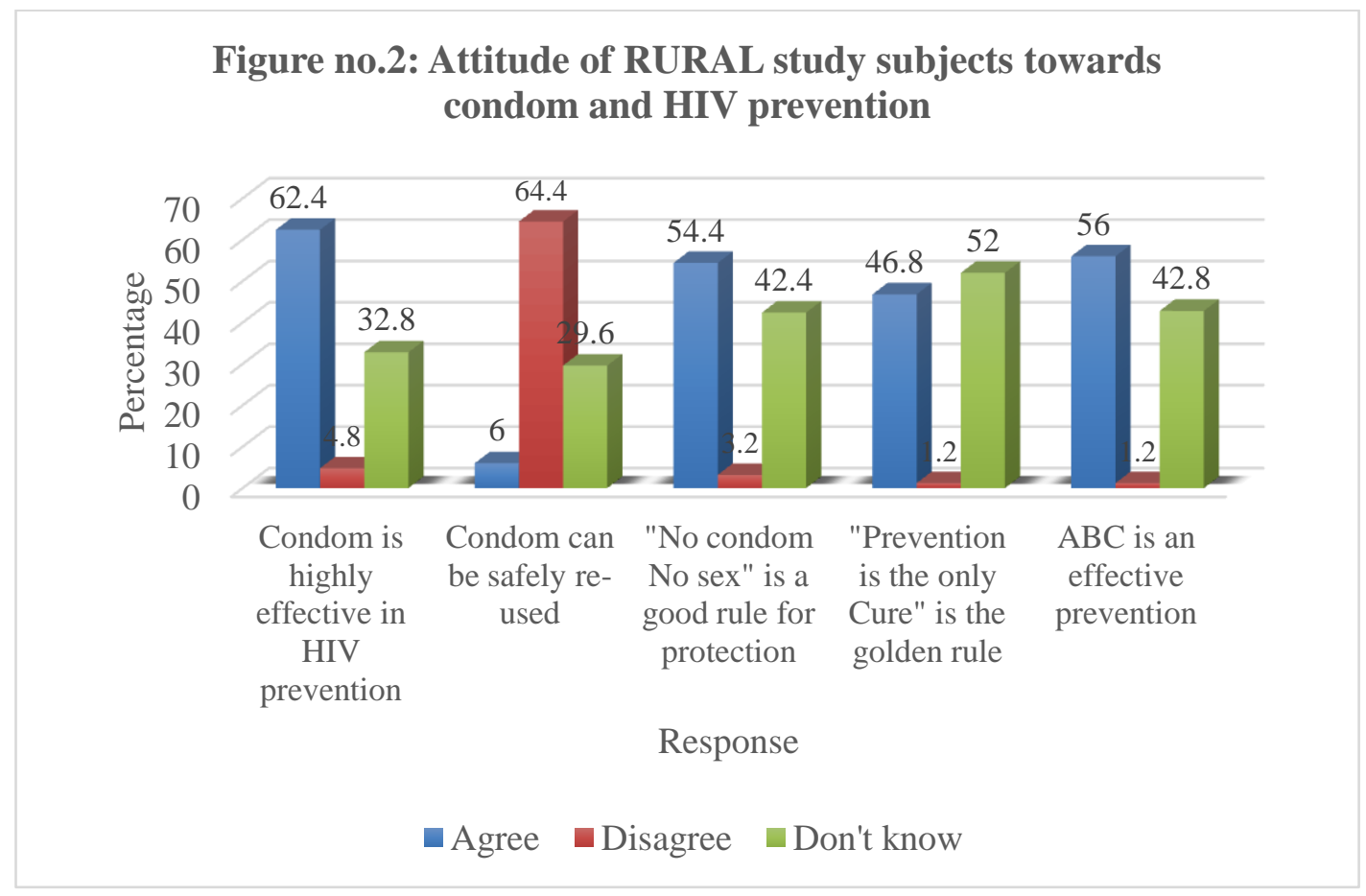

$124(12.4 \%)$ of the study subjects agreed that one could get HIV by sharing food, combs, sheets or sitting closely with an HIV infected person. On similar lines was the response when asked if one could get HIV by shaking hands, touching or holding an infected person as is evident by 126 $(12.6 \%)$ of the respondents agreeing. On the issue of hugging and kissing leading to the infection, 378 (37.8\%) agreed. $168(16.8 \%)$ participants agreed that one could get infected by sharing toilets or latrines with infected persons. Finally on the myth that HIV can be got by working near somebody who is infected, $116(11.6 \%)$ of the total respondents agreed.

\section{Discussion}

On asking if HIV people be discriminated with, 94.8\% disagreed. Parmar et $\mathrm{al}^{3}$ (2014) found that $87.8 \%$ of their Belgaum's urban community study subjects had positive attitude towards people suffering from HIV/AIDS and Chaudhary et al ${ }^{4}$ (2011) in their study on auto drivers revealed that $69.59 \%$ said they would remain friends with infected persons.

A mere $3.2 \%$ of our study subjects agreed that HIV patients should be forced to live away from others. However, Igboanusi et $\mathrm{al}^{5}$ (2015) in their attitude and knowledge study towards the diseased among Nigerian military recruits found $31 \%$ subjects agreeing that such people should be isolated and $16.7 \%$ saying that they should not be supported by society. This difference may be attributed to high burden of the disease and the associated fear and paranoia surrounding it, in most of the African countries.

$2.6 \%$ of the study subjects disagreed when asked if HIV infected people be sympathized with. Gupta et $\mathrm{al}^{6}$ (2014) in their Lucknow study found 
that $6.5 \%$ senior secondary school students hated such people. In total $94 \%$ subjects agreed over the same issue vis-à-vis Bhagavathula et $\mathrm{al}^{1}$ (2015) finding where $54.8 \%$ of adult family members of people living with HIV, said they felt empathetic towards HIV patients. The difference could be due to the fact that the later study was conducted in Telangana, which has different cultural milieu than Ambala, Haryana.

$90.4 \%$ of the total study subjects agreed that they would get tested, if they thought they might have HIV. Basavarajuet $\mathrm{al}^{7}$ (2016) in their Telangana study concluded that $63.8 \%$ of the subjects were willing to go for voluntary testing. The difference could be attributed again to the cultural differences between the two parts of India.

Pertaining to the same question, attitude of 18-30 age group subjects, male subjects, educated subjects, high socio-economic status subjects and Christian and Sikh subjects was more favorable $(p<.05)$. Illiterate fishermen were two times more likely and to have negative attitudes $(p=.02)$ towards HIV/AIDS, as per Zafar and Nisar $^{8}$ (2014) HIV/AIDS study among adult fishermen in coastal areas of Karachi.

Shah et $\mathrm{al}^{9}$ (2015) in their knowledge and attitude study among senior secondary school students in Pune found that $72.3 \%$ of children agreed that condom is highly effective in HIV prevention, just like $76 \%$ of our total study subjects. Again a striking similarity in results was found on the question if a condom be safely re-used between our study (4.2\% agreeing) and Agyeiet $\mathrm{al}^{10}$ (2002) study among young people in Ghana $(5 \%$ agreeing).

69\% subjects in our study agreed that Abstinence, Being faithful and Consistent Condom usage $(\mathrm{ABC})$ is an effective HIV prevention. Igboamusi et $\mathrm{al}^{5}$ (2015) in their Nigerian military recruits study found $69.3 \%$ of the personnel stated that not having sex at all is an effective prevention, while Christiane et $\mathrm{al}^{11}$ (2014) in their Gabon study concluded that $72.3 \%$ of young people agreed that remaining faithful is an effective prevention.
$90 \%$ of the urban and $60 \%$ of rural respondents in our study disagreed that one could get HIV by sharing food, combs, sheets or sitting closely with an HIV. Sunil et al $^{12}$ (2011) found $71.43 \%$ urban and $58.67 \%$ rural Bangalore high school students to be disagreeing with the same.

$10.8 \%$ of our study subjects said that HIV could spread by shaking hands, like the cross-sectional study result $(8.7 \%)$ by Parmar et $\mathrm{al}^{3}$ (2014) in urban community of Belgaum city.

When asked if one can get infection by kissing/hugging an HIV person, $37.8 \%$ agreed. Unnikrishnan et $\mathrm{al}^{13}$ (2010) found only $12 \%$ agreeing to the same statement, probably because the study is done in the high prevalence state of Karnataka, which is more in the focus of IEC activities. The same logic could explain the difference between $16.8 \%$ our study subjects agreeing to the spread of the virus by sharing toilets infected with HIV positive people and $7 \%$ in the later study.

\section{Conclusion}

It was found that overall attitude of the study subjects regarding HIV/AIDS is appreciable, in both urban as well as rural areas. The participants attitude was found to be heartening, still there is no room for complacency!

\section{Bibliography}

1. Bhagavathula AS et al. A cross sectional study: the knowledge, attitude, perception, misconception and views (KAPMV) of adult family members of people living with human immune virus-HIV acquired immune deficiency syndrome-AIDS (PLWHA). Springer Plus 2015;4:769-774.

2. Kaur H, Singh GPI, Soni RK. A community based study of HIV/AIDS knowledge among housewives of rural and urban background in Punjab. Int $\mathrm{J}$ Res Health Sci (Internet). 2014;2(1):236-42. Available from http://www.ijrhs.com/issues.php?val=Volu me2\&iss=Issue 1 
3. Parmar S, Bellad A. The Knowledge and Attitude of Married women towards HIV/AIDS in an urban community of Belgaum city, Karnatakas- A crosssectional study. Internal Journal of Interdisciplianary and Multidisciplianary Studies 2014;1(5):337-343.

4. Chaudhary SS, Nagargoje MM, Kubde SS, Bhardwaj AK, Singh R. Knowledge and attitude of auto-rickshaw drivers about HIV/AIDS and other sexually transmitted diseases. Indian Journal of Dermatology, Venereology and Leprology. 2011;77(2):197-199.

5. Igboaanusi CJC, Dahiru $\mathrm{T}$, Joshua IA. HIV/AIDS Knowledge and Attitude among Military Recruits at Depot Nigeria Army, Zaria, Nigeria. American Journal of Public Health Research 2015;3(1):8-14.

6. Gupta P,Anjum F, Sachan B, Srivastava JP, Zaidi ZH. Knowledge attitude and practices regarding prevention of HIV/AIDS amongst secondary school students in Lucknow. National Journal of Medical and Allied Sciences 2014;3(2):3538.

7. Basavaraju A, Lakshmi S. Awareness about HIV/AIDS among medical entrants: A questionnaire study. National Journal of Basic Medical Sciences 2016;6(1):14-17.

8. Zafar M, Nisar N, Kadir M, Fatmi Z, Ahmed Z, Shafique K. Knowledge, attitude and practices regarding HIV/AIDS among adult fishermen in coastal areas of Karachi. BMC Public Health 2014,14:437444.

9. Shah DR, Tuli A, Vaidya V. Knowledge and Attitude Towards HIV/AIDS Among Senior Secondary School Children in Pune. Indian Journal of Applied Research. April 2015;5(4): 481-483.
10. Agyei WK, Biritwum RB, Ashitey GA. HIV/AIDS awareness and sexual behavior among young people in Ghana. Ghana Medical Journal 2002; 36(3):94-101.

11. Christiane NA, Roger ZM, Masika J, Zhang Y, Liang Z. HIV/AIDS prevalence, knowledge, attitudes and related behaviors among young people in Libreville, Gabon. Journal of Humanities and Social Science. Jan 2014;19(1):59-65.

12. Sunil B, Arigela K. Knowledge and attitude of high school students regarding human immunodeficiency virus, acquired immunodeficiency syndrome and sexually transmitted diseases. Int J Res Health Sci. 2014 Jan;2(1):182-9.

13. Unnikrishnan B, Mithra PP, Rekha T, Reshmi B. Awareness and attitude of the general public toward HIV/AIDS in coastal Karnataka. Indian J Community Med 2010;35(1):142-6. 